\title{
Learning Media Development: FireDroid Application Base on the Android System and Distance Learning
}

\author{
Anton Abdullah, Wildan Nugraha, Sutiyo, Reyvaldo Fajriansyah Setiawan, Muhammad \\ Iqbal Dwi Saputra, Ridho Priyama Putra \\ Politeknik Penerbangan Palembang \\ * e-mail: anton@poltekbangplg.ac.id
}

\begin{abstract}
Abstrak
The purpose of this research is to design and develop an Android-based learning media application for the Fire Fighting Equipment course at the Diploma Three PPKP Study Program, Palembang Aviation Polytechnic. The research method used is Research and Development (R\&D). This stage of research is 1) Potential and problems; 2) Data collection, 3) Product design, 4) Design validation; 5) Design revisions; 6) Product trials; 7) Design revisions; 8). Usage trials; 9) Revision of the final design; 10) Mass products. User satisfaction questionnaires are used in product success analysis to determine user replies. Responders responded strongly to the response interval of 71-80 people (82.6\% $93 \%$ ) of the 86 answers, a scale of 4 with the category Very Good (A). The expected benefit is that this learning media can be one of the tools in the lecture process at Palembang Aviation Polytechnic. This research is in the form of a Research Results Report and Intellectual Property Copyright.
\end{abstract}

Keywords: E-Book; Learning Media; Multimedia.

\section{INTRODUCTION}

Education is a deliberate and planned effort to create a learning environment and learning process in which learners actively develop their potential for religious-spiritual strength, self-control, personality, intelligence, noble morals, and the skills required for themselves, society, nation, and state (UndangUndang No. 20, 2003). At the same time, the influence of education and training programs variables on performance shows a very high correlation and is positive (A. Abdullah, 2020).

Mobile platform devices, notably Android, have evolved from communication tools to sociability, entertainment, and learning tools to promote mobile technology and boost their affordability and broad capabilities. This has had a significant impact on how the world works, including how people learn. Learning via mobile or Mobile Learning has become part of the educative process. Mobile learning is a type of e-learning that provides educational content and learning supporting materials through wireless communication devices (Christianne, 2013).

Mobile learning does not replace direct face-to-face learning in the classroom; rather, it serves as a supplement to the learning process and can be utilized by students to relearn material that has been forgotten, anywhere and at any time. Students need teaching materials provided by lecturers from e-learning, through e-learning they can see the display of material every week and have been composed of material from the first meeting to the last meeting (Lira, 2020)

Palembang Aviation Polytechnic is a government high school run by the Ministry of Transportation's Human Resources 
Development Agency. It offers a variety of study programs, including the Diploma 3 Aviation Fire and Rescue Study Program. The Study Program, especially in Fire Fighting Equipment courses has not utilized Androidbased learning media. The learning media applied is still limited to the PowerPoint presentation slide. With the PowerPoint media, many learners pay less attention to the explanation of the lecturer. Especially in the Covid-19 Pandemic as it is today where all learning is carried out with distance learning methods, which can cause saturation of cadets in KBM semester 1 with online methods using zoom and learning management system (LMS) applications.

Therefore, it can be seen that the media PowerPoint encourages students to learn actively, and the learning process becomes less effective because the material delivered is not optimally accepted. In addition, often learners do not study and evaluate the modules or materials that have been given. Furthermore, many students fail to examine and assess the courses or materials they are given.

Many formats can be utilized by developers, one of the best in the format with .apk extensions or applications. Applications can contain both silent and mobile devices such as images, videos, audio, or animations so that the appearance of electronic books can be packed interactively. A platform is required to read the application format on a device (Wikipedia, 2021).

Android is the platform with the bestsupporting features because it can receive many kinds of features on computer devices. Books in the form of android-based apps are also being attracted by cadets because they make the display of learning media more attractive and flexible. In addition, e-books need to be developed because they can solve the difficulties of learning visualization and the practical benefits of bringing textbooks, especially based on Android (Via Wulandari et al, 2019). But unfortunately, in some studies, e-books were developed with the help of Adobe Flash Professional software. Himmah (2017) said that Adobe Flash Professional software is quite difficult to learn because it contains a programming language, so it is more appropriate to be used by developers who already have expertise in the field of Information and Communication Technology.

To deliver material content to the Fire Fighting Equipment lesson with an androidbased display, an application learning media development is required based on the needs of these learners.

\section{METHODS}

Palembang Aviation Polytechnic is the location of this research site. The study period is 6 (six) months, from May to October 2021.

The Research and Development (R\&D) approach is used in this type of study. The R\&D method is a research method that is used to develop a product and evaluate its effectiveness (Sugiyono, 2015). The research steps are depicted in the diagram below.

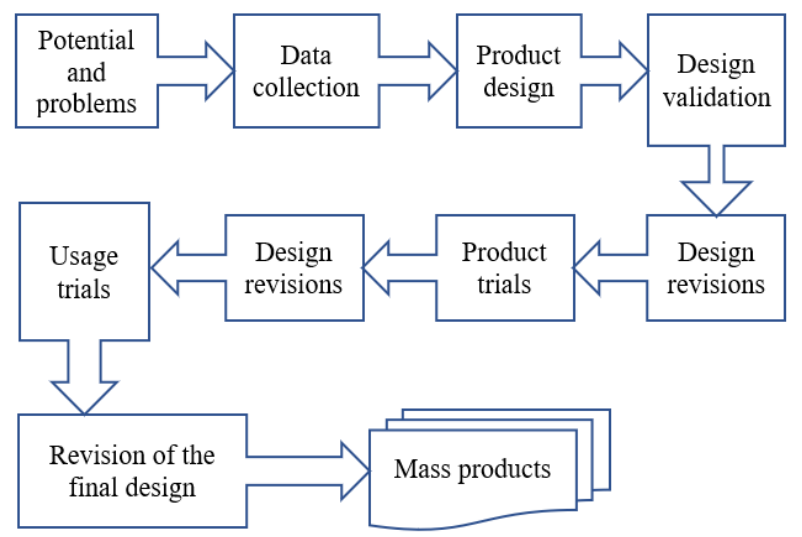

Figure 1. Steps to use Research and Development methods (Sugiono, 2015)

The first stage, solving the problem and analyzing the needs is a step information collected in the form of problems related to learning activities and characteristics of cadets.

In the data collection stage, is carried out in two steps, namely: (1) Field surveys, aiming to collect data related to design and implementation, (2) Literature studies, used to study concepts or theories related to androidbased learning media to be developed. The Product Design stage is designing a base on an android learning media with the main software, combining all sources of material, problem training, and animated videos, and other content. 
Design Validation stage, at this stage the product design will be validated by experts (qualitative analysis). Validation aims to provide advice or responses to the learning media (product) to be developed. While quantitative analysis is used to analyze data from the respondent's questionnaire. The formula used to find out the score of the questionnaire is:

$$
\text { Persentase }=\sum x \mathrm{SMI} \times 100 \%
$$

Description: $\quad \sum \quad \mathrm{x}=$ Number of scores, SMI=Score Maximum Ideal (Source: Tegeh et al., 2014)

To get a conclusion of the level of validity of the product development results, then look at the criteria for validity in Table 1.

Table 1. Validity Criteria

\begin{tabular}{ll}
\hline Criteria & Category \\
\hline $85,01 \%-100,00 \%$ & $\begin{array}{l}\text { Very valid, or can be } \\
\text { used without revision }\end{array}$ \\
$70,01 \%-85,00 \%$ & $\begin{array}{l}\text { Valid enough, or it } \\
\text { can be used but } \\
\text { necessary small } \\
\text { revised }\end{array}$ \\
& $\begin{array}{l}\text { Less valid, or can } \\
\text { used but necessary } \\
\text { major revision }\end{array}$ \\
& Invalid, or unusable \\
\hline
\end{tabular}

Source: (Akbar, 2013)

In the Design Revision Stage, after the product is completed validation by experts, there will be weaknesses from the product. The weakness will then be corrected according to the advice given by the expert validator. So that the resulting learning media is appropriate and suitable for use.

Product Trial Stage, product trials will be conducted by means of installation of applications to Android smartphones owned by cadets Prodi D3 PPKP Palembang Aviation Polytechnic. At the time the trial was conducted, cadets were given instruments in the form of questionnaires to respond to the resulting products. It aims to find out the response of cadets to the development of Android-based learning media and learners' learning outcomes. To get a level conclusion on the practicality of using resulting products development in field tests, then see the practicality criteria in Table 2 .

Table 2. Practicality Criteria

\begin{tabular}{ll}
\hline Criteria & Category \\
\hline $85,01 \%-100,00 \%$ & Very practical \\
$70,01 \%-85,00 \%$ & Quite practical \\
$50,01 \%-70,00 \%$ & Less practical \\
$01,00 \%-50,00 \%$ & Impractical \\
\hline
\end{tabular}

Source: (Akbar, 2013)

After the trial, if an error is found or there is still a discrepancy, then continue with the design revision. Furthermore, if there are no adjustments and revisions again will be continued with mass production.

\section{RESULTS AND DISCUSSIONS}

\section{Stage 1: Potential and problems:}

Learning media on PSDT PPKP applied is still limited to PowerPoint presentation slides. With the PowerPoint media, many cadets pay less attention to the explanation of lecturers (media power point less encourage students to study actively). In addition, the delivery of material during the pandemic online is displayed through the zoom application. This is sometimes and the problem that often occurs is the limited quota of cadets and also the main problem is the quality of the network so that making audio and even slide material displayed experiencing delay or lag (broken) so that the information to be conveyed by lecturers is not maximally captured by cadets.

\section{Stage 2: Data collection;}

Data collection is done in two steps, namely:

1) Field survey;

The steps at this stage aim to collect data about planning and implementation. The data collected according to the needs of application creation is as follows:

a) Selected Lesson

Table 3. Selected Lesson

\begin{tabular}{ll}
\hline The Lesson & Fire Fighting Equipment \\
\hline Semester & 1 \\
\hline Code & 5PKPC1004 \\
\hline SKS & $\begin{array}{l}\text { 4 Credits (2 Credits Theory, 2 } \\
\text { Credits Practice }\end{array}$ \\
\hline $\begin{array}{l}\text { Achievement } \\
\text { of Course }\end{array}$ & $\begin{array}{l}\text { Able to operate firefighting } \\
\text { equipment according to } \\
\text { Learning }\end{array}$ \\
\hline pescription & In this course, Cadets learn \\
\hline
\end{tabular}




\begin{tabular}{ll}
\hline & $\begin{array}{l}\text { about the types of fire } \\
\text { suppression equipment and } \\
\text { how it is operated. }\end{array}$ \\
\hline Study & 1) General Concept of Fire \\
Materials & Fighting Equipment \\
& 2) Fixed Fire Appliances \\
3) Fixed mobile fire \\
appliances
\end{tabular}

\section{Source: PPSDMPU, 2019}

b) Applications used

Kodular Creator, apps used for the android platform. Just drag n' drop a few components, join some blocks and voila! You have just created your awesome app. To create interesting material content, we use the Canva app. Quizizz platform is used for exercise, assessment, and final tests. Other applications used are google forms for the use of user satisfaction and criticism/suggestions.

\section{2) Literature Study}

Used to learn concepts or theories related to Android-based learning media to be developed (attached in the references). Product design results in a distance learning-based e-book application product that is adapted to the PPKP PSDT Curriculum and Syllabus that has been endorsed by the Head of the Transportation Human Resources Development Agency.

\section{Stage 3: Product design}

This product design uses the Codular Creator application as the main software. The application contains preliminary sections (front cover, title page, foreword, book usage instructions, table of contents, drawing list, table list), contents (Basic competencies and learning objectives, initial competency tests, concept maps, and keywords, materials, additional features, summaries, and chapter competency tests), as well as closing (end-ofsemester competency test, bibliography, author identity, glossary, index). The description of this product design is as follows:

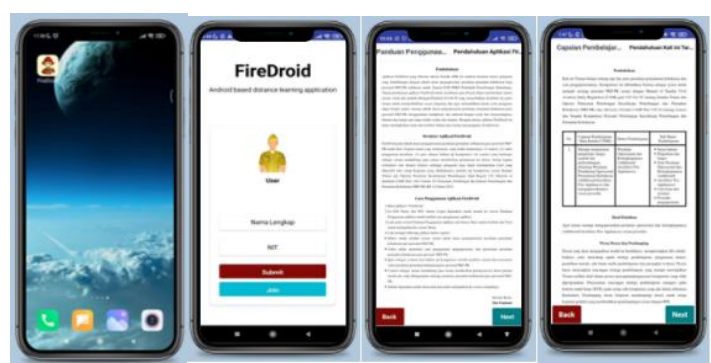

Figure 2. App view after it's posted on Android

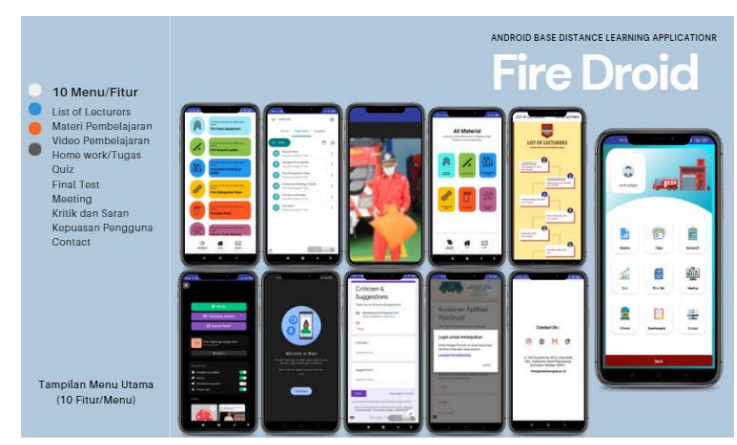

Figure 3. Main Menu

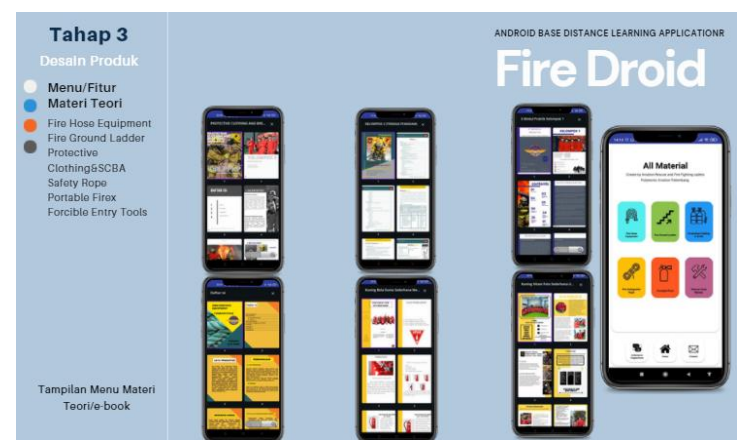

Figure 4. Theoretical Material Menu

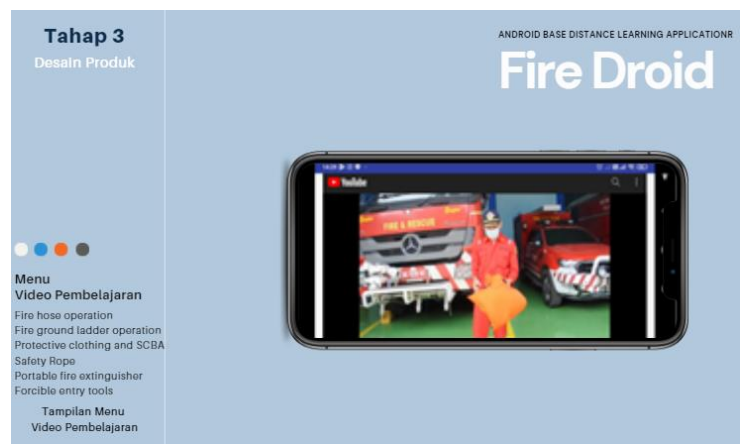

Figure 5. Video Material Menu

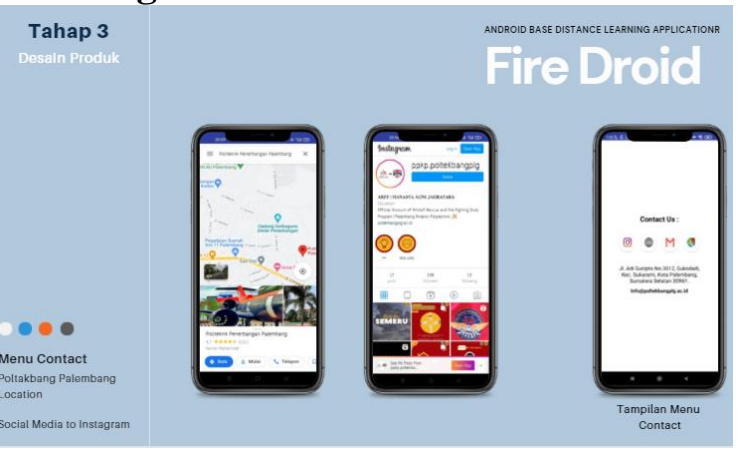


Figure 6. Contact Menu

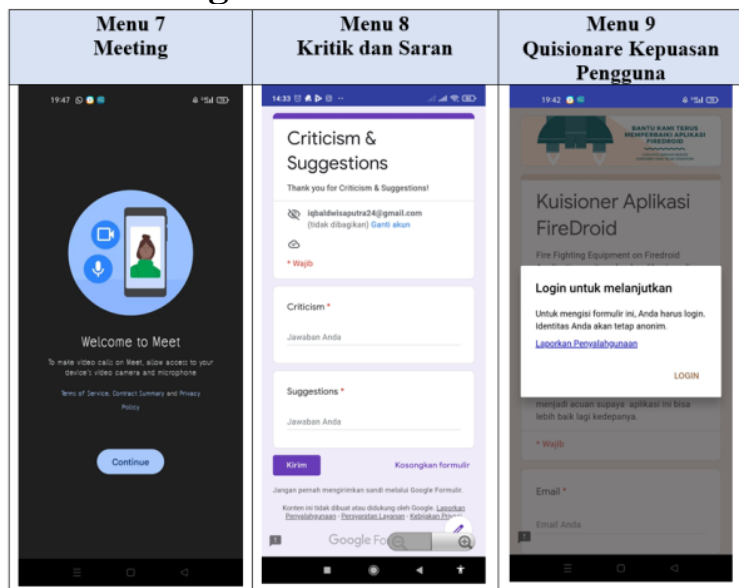

Figure 7. Meeting, Criticsm\&Sugestion, Questionary Menu

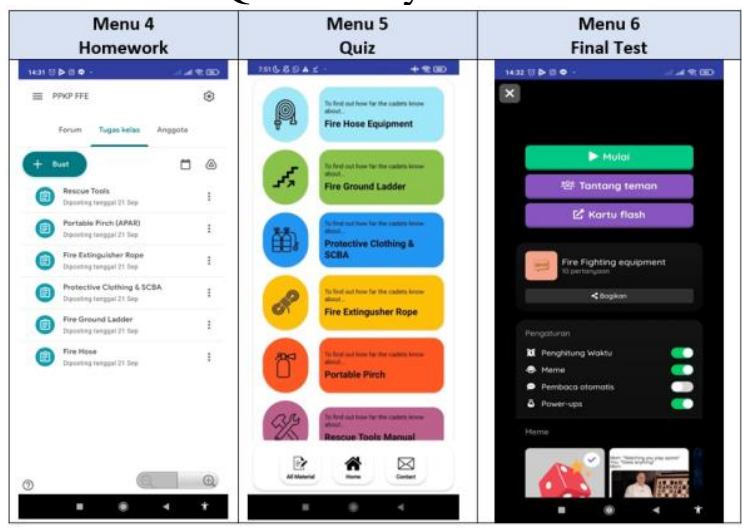

Figure 8. Homework, Quiz, Final Test Menu

\section{Stage 4: Design validation;}

Aspects of e-module content evaluated by two experts in their fields consist of three indicators divided into several points to measure the feasibility of the material presented. The three indicators are clarity, material substance, and language used. The results of the validator's assessment of the emodule content are seen in Table 4.

Table 4. Results of the validator's assessment of the application (Quality Result)

\begin{tabular}{llrrl}
\hline No. & Indicator & Average & Percentage & Result \\
\hline 1 & clarity & 3,550 & $88,77 \%$ & $\begin{array}{l}\text { Very } \\
\text { valid }\end{array}$ \\
2 & $\begin{array}{l}\text { material } \\
\text { substance }\end{array}$ & 3,504 & $87,57 \%$ & $\begin{array}{l}\text { Very } \\
\text { valid }\end{array}$ \\
3 & $\begin{array}{l}\text { language } \\
\text { used }\end{array}$ & 3,558 & $87,95 \%$ & $\begin{array}{l}\text { Very } \\
\text { valid }\end{array}$ \\
\hline Average & 3,537 & $88,09 \%$ & $\begin{array}{l}\text { Very } \\
\text { valid }\end{array}$ \\
\hline
\end{tabular}

Based on the data in table 4, it can be seen that the results of validator assessments of emodule content developed looking at several indicators, get an average value of 3,537 with a percentage of $88.09 \%$ or categorized as very valid.

\section{Stage 5: Design revisions;}

Products that are considered worthy of field trials with little revision. The advice given by validators for the perfection of basic problembased programming e-module content, namely 1) still needs to adjust the content of the material with syllabus; and 2) foreign language writing italicized.

\section{Stage 6: Product trials;}

Product trials are conducted by means of the installation of applications to Android smartphones owned by users. This is done to answer the practicalities of the development of an Android-based e-book teaching materials application, which is done by spreading questionnaires consisting of 20 questions that include components of language feasibility, content feasibility, and graphics feasibility in the application.

The media aspect of the e-module evaluated by experts in their field is to lead to the appearance of the e-module, consisting of three indicators divided into several points. The three indicators are design graphic feasibility, visual communication, and practicality. E-module display validator assessment results seen in Table 5 .

Table 5. Result of the Practicality Criteria

\begin{tabular}{llrrl}
\hline No. & Indicator & Average & $\begin{array}{l}\text { Percenta } \\
\text { ge }\end{array}$ & Result \\
\hline 1 & $\begin{array}{l}\text { design } \\
\text { graphic } \\
\text { feasibility } \\
\text { visual } \\
\text { communica } \\
\text { tion } \\
\text { practicality }\end{array}$ & 3,581 & $89,50 \%$ & $\begin{array}{l}\text { Very } \\
\text { practical }\end{array}$ \\
3 & 3,721 & $93,00 \%$ & $\begin{array}{l}\text { Very } \\
\text { practical }\end{array}$ \\
\hline Average & 3,566 & $89,13 \%$ & $\begin{array}{l}\text { Very } \\
\text { practical }\end{array}$ \\
\hline
\end{tabular}

The respondents' questionnaires were distributed to 106 people, consisting of: 1) 49 cadets of PSDT PPKP; 2) 48cadets of PSDT MBU; 3) 4 ARFF personnel; 4) 5 Lecturers and education personnel of PSDT PPKP Poltekbang Palembang. The response questionnaire consists of two indicators, namely ease, and benefits that are divided into 
several assessment points. Data from the analysis of student response questionnaires can be seen in Table 6.

Table 6. Results of Response Questionnaire Analysis

\begin{tabular}{llrrl}
\hline No. & Indicator & Average & $\begin{array}{l}\text { Percenta } \\
\text { ge }\end{array}$ & Result \\
\hline 1 & $\begin{array}{l}\text { Ease of } \\
\text { using the } \\
\text { app } \\
\text { benefit }\end{array}$ & 3,488 & $87,20 \%$ & $\begin{array}{l}\text { Very } \\
\text { practical }\end{array}$ \\
\hline Average & 3,465 & $86,63 \%$ & $\begin{array}{l}\text { Very } \\
\text { practical }\end{array}$ \\
\hline
\end{tabular}

Based on the results of the response questionnaire analysis of e-module application products in table 6 , there was an average value of 3,477 with a percentage of $86.91 \%$ of the two assessment indicators. It can be concluded that FireDroid Application Base on the Android System and Distance Learning is categorized as very practical.

Stages, 7-9 (design revision, use trial, final design revision) is no longer done because the results of the application product trials are not problematic (valid and practical) so that it can be continued to the next stage.

\section{Stage 10: Mass products.}

Mass product implementation will be applied to the learning process of Semester Gasal (semester 1) of Fire Fighting Equipment class in the 2022-2023 school year. For the next development process will be hosted to google play or play store using the Poltekbang Palembang domain to be used for the public.

\section{CONCLUSION}

Based on the data of evaluation and discussion results, the conclusion that can be presented is the development of FireDroid Application Base on the Android System and Distance Learning by using research methods to produce certain products, and testing the effectiveness of the product (Sugiyono, 2015) can be used as another alternative in distance learning media in PSDT PPKP Poltekbang Palembang. The results of the validation analysis from validation experts get a value of $88.90 \%$ (clarity of content) and $89.13 \%$ (practicality) while the results of practicality analysis based on responder questionnaires get a value of $86.91 \%$. This shows that the application developed is very valid according to the criteria of validity and is very practical to use in the learning process in Fire Fighting Equipment courses.

\section{REFERENCES}

A Abdullah. 2020. Relationship the Work Culture and Training Programs Within Performance. International Journal of Progressive Sciences and Technologies (IJPSAT) ISSN:25090119 ISSN-L: 2509-0119 ResearcherID: J1399-2016. Vol. 20 No. 1 April 2020, pp. 92-101

https://ijpsat.ijshtjournals.org/index.php/ijpsat/article/view https://scholar.google.com/citations?user

Akbar, S. 2013. Instrumen Perangkat Pembelajaran. PT Remaja Rosdakarya.

Arikunto, Suharsimi. 2010. Prosedur Penelitian Suatu Pendekatan Praktik. Jakarta: PT Rineka Cipta.

Arsyad, Azhar. 2014. Media Pembelajaran. Jakarta: Rajawali Pers.

Christianne Lynnette G. Cabanban, MIT. 2013. International Journal of Information Technology \& Computer Science: Development of Mobile Learning Using Android Platform, (Online), Vol 9, Nomor 1 , (http://ijitcs.com/volume\%209_No_1/Ch ri stianne.pdf., diunduh 28 Maret 2016).

Hayu, Lira. 2020. Student's Needs for Teaching Materials in the Era of Pandemic.

https://doi.org/10.26499/rnh.v10i1.3651

Himmah. 2017. Pengaruh Model Pembelajaran Biologi Berbasis Reading-Concept MapReciprocal Teaching Dan Gender terhadap Keterampilan Berpikir Kreatif Siswa Kelas X SMA Negeri 7 Malang.

Pusat Pengembangangan Sumber Daya Manusia Perhubungan Udara. 2019. Kurikulum Program Studi Penyelamatan dan Pemadam Kebakaran Penerbangan (PPKP) Program Diploma III

Program Studi Diploma Tiga Penyelamatan dan Pemadam Kebakaran Penerbangan. 2020. Rencana Pembelajaran Semester 
Sugiyono. 2015. Metode Penelitian Pendidikan. Bandung: Alfabeta.

Tegeh, I. M., Jampel, I. N., \& Pudjawan, K. (2014). Model penelitian pengembangan. Yogyakarta: Graha Ilmu.

Undang-Undang Republik Indonesia Nomor 20 Tahun 2003 tentang Sistem Pendidikan Nasional. 2012. Bandung: Citra Umbara.

Wikipedia. 2021. Cross-platform software. Cross-platform software - Wikipedia

Wulandari, Via., Abidin, Zainul., Praherdhiono, Henry. 2019. Pengembangan Media Pembelajaran E-Book Infografis Sebagai Penguatan Kognitif Siswa $X$ Mia. http://journal2.um.ac.id/index.php/jktp/index 